\title{
FILOZOFIA I KONIUNKTURA
}

\section{ANTONIO NEGRI}

\begin{abstract}
Abstrakt: W tekście, na który składają się dwie pierwsze części drugiego rozdziału książki Descartes politico, Antonio Negri definiuje zmianę dokonującą się w myśli Kartezjusza u progu lat 30. XVII wieku. Kluczowa dla analiz Negriego kategoria oddzielenia ujęta zostaje w ścisłym związku z załamaniem koniunktury gospodarczej i głębokim kryzysem projektu renesansowego. Negri stara się uchwycić moment narodzin barokowego Kartezjusza i wskazuje na dynamiczne napięcie między filozofią kartezjańską tego okresu a światopoglądem libertyńskim. To właśnie niejednoznaczna relacja z libertynizmem, stanowiącym odpowiedź na upadek renesansowych nadziei i aspiracji, stanowi, wedle Negriego, punkt wyjścia dla kartezjańskich poszukiwań sposobu przezwyciężenia kryzysu.
\end{abstract}

Słowa kluczowe: Kartezjusz, oddzielenie, koniunktura, renesans, pamięć, libertynizm, Bóg, burżuazja. 
„Powie Ci ktoś, że gdyby Bóg ustanowił owe prawdy, to mógłby je zmieniać tak, jak to król robi ze swymi prawami, na co należy odpowiedzieć, że owszem...” (AT I 145$\left.146^{1}\right)$.

Jest rok 1629. Descartes na dobre osiadł w Niderlandach. Żyje samotnie, ,dans le desert’(AT I14).To samotność pożądana, chroniona, stąd powtarzające się apele do przyjaciół, by nie ujawniali miejsca, w którym się ukrywa. Wkroczenie w dojrzałość, ostateczny wybór powołania filozoficznego, są zatem aktem oddzielenia od świata. Dlaczego? ${ }^{2}$

Jak widzieliśmy, pierwszą oznaką tej nowej drogi intelektualnej wydaje się być zadanie prześledzenia na nowo „historii siebie samego”. Teraz to zadanie jawi się już jako problem, przemiana zaś -jako zerwanie. „Historia samego siebie” jest przede wszystkim problematyczna w tej mierze, w jakiej dotyka problemu pamięci i pyta, co prawdziwie wyróżnia pamięć. Problem pamięci jako problem oddzielenia? Studium bonae mentis - krótki traktacik ułożony być może w tym okresie³ - zmierza właśnie do ugruntowania radykalnej integralności intelektualnej władzy sądzenia, przeciwstawionej i uwolnionej od obciążeń nieproduktywnej i wyalienowanej przeszłej wiedzy (nowa polemika z ekstrawagancjami lullistów i różokrzyżowców!) (AT X 191, 191-192, 193-197, 198-200). I natychmiast rozwiązuje ten problem poprzez odróżnienie duszy i intelektu od pamięciowej materialnościi nawyku. „Musimy zauważyć dużą dysproporcję między jego pamięcią a intelektem. On nie odwoływał się niemal zupełnie do pamięci miejscowej. Być może, podczas swego odosobnienia zaniechał kształtowania pamięci cielesnej, która wymaga częstych ćwiczeń, koniecznych do utrwalania przyzwyczajeń. Z pewnością nie mógł narzekać na pamięć, którą nazwał intelektualną, to jest zależną od samej duszy. Jej zakres bowiem nie ulega powiększeniu ani też zmniejszeniu” (AT X, 201)

${ }^{1}$ Skrót AT odsyła do francusko-łacińskiego wydania pism Kartezjusza: Charles, Adam i Paul Tannery. 1964 1971. Oeuvres de Descartes. Paris. Cyfra rzymska wskazuje numer tomu, cyfra arabska - numer strony (przyp. thum). Fragment listu do Mersenne'a z 15.04.1630 roku jest dostępny w języku polskim w: (Alquié 1989, 185).

2 Między G. Cohenem (1920) i E. Gilsonem (1930) wywiązała się dyskusja na temat powodów przeprowadzki do Holandii. Nie wydaje się, aby podawane przez jednego bądź drugiego autora przyczyny były przekonujące. Cohen utrzymuje, że Descartes, znany jako antyarystotelik, był zmuszony uciekać z Paryża z obawy przed prześladowaniami. Gilson zdołał z łatwością wykazać (Gilson 1930, 271), że bardzo wielu antyarystotelików żyło w tym czasie bezpiecznie w Paryżu. Ale w takim razie dlaczego mielibyśmy sądzić, jak chciał Gilson, że Descartes szukał w Holandii „spokoju”? Przenosiny do Holandii sa w rzeczy samej poszukiwaniem „oddzielenia”.

3 Wydaje się, że można postrzegać ową pracę jako wytwór tego okresu, choćby ze względu na fundamentalnie pasująca do niego problematykę. Inaczej, por. E. Gilson $(1925,180)$, który datuje powstanie Studium nawet na rok 1620; Sirven $(1930,292-293)$ umieszcza je z kolei w roku 1623. W każdym razie zob. zachowane fragmenty w AT X 191-203: chodzi o serię cytatów zebranych u Bailleta. Ogólniej, zob. też Garin (1967, LIV i n.).

${ }^{4}$ Fragment Studium bonae mentis jest dostępny w języku polskim w: (Ziółkowski 1989, 146-147). 
W ten sposób kształtuje się problematyczny obraz radykalnego oddzielenia czystej myśli i jej nauki od nauki pamięci i doświadczenia: „Descartes podzielił nauki na trzy zasadnicze grupy. Pierwsza, która obejmuje nauki zwane głównymi, odznacza się tym, iż są one najbardziej ogólne i wyprowadzają swoje wnioski z prostych i powszechnie znanych zasad. Druga grupa to nauki nazwane eksperymentalnymi, które nie mają jasnych zasad, czyli pewnych dla wszystkich, a tylko dla tych, którzy poznali je z własnego doświadczenia i obserwacji. Jakkolwiek są i tacy, którzy poznali je w sposób demonstratywny. Do trzeciej grupy Descartes zaliczył nauki, które nazwał wolnymi, a które - prócz poznania prawdy jako niezbędny warunek wymagaja pewnej bystrości umysłu albo przynajmniej wyuczonych nawyków" (AT X 202)(Ziółkowski 1989, 147).

Samotność, spotkanie z samym sobą, problem pamięci, zmaganie z pamięcią. Ale teoretycznie ujęty problem pamięci nie może zostać oddzielony od problemu tego, co historycznie się na nią składa, od całości doświadczenia, jakie zarejestrowała: jeśli więc pamięć jest nawykowym utrwaleniem przeżytego doświadczenia, cielesnym znakiem uczestnictwa w humanistycznej przygodzie, zmaganie z pamięcią odsyła bezpośrednio do horyzontu ogólnego, problem ujawnia bezpośrednie konsekwencje metafizyczne. Oddzielając się, bona mens wymaga całościowego wyjaśnienia własnego oddzielenia. Zatem mądrość ufundowana na pewnym siebie przywłaszczeniu świata, na bezpośrednim związku z rzeczywistością, nie jest tu już możliwa: odwrotnie, tylko abducere mentem a sensibus [odłączenie umysłu od zmysłów] pozwala nowej propozycji filozoficznej zmierzać ku mądrości ${ }^{5}$. Jest to sytuacja oddzielenia i trzeba, by z oddzielenia pochodził problematyzujący impuls. W tej atmosferze zdaje się rozwijać Traité de la Divinité, „który rozpocząłem we Fryzji, a którego zasadnicze punkty maja dowieść istnienia Boga i istnienia naszych dusz po odłączeniu od ciała..." (AT I 1826). Temu właśnie Descartes poświęca pierwsze dziewięć miesięcy dobrowolnego wygnania w Holandii ${ }^{7}$ : badaniu metafizycznemu, które znajduje wyraz w odkryciu fundamentalnej roli krytyki pamięci! Oddzielenie mieści się więc, musi się mieścić, w wymiarze metafizycznym.

\footnotetext{
5 Zob. (Gilson 1925, 81-83); (Gilson 1930, 265-266). W obu przypadkach Gilson kładzie nacisk na stoickie pochodzenie terminu bona mens. Jakkolwiek ma z pewnością rację, nie może to - moim zdaniem - być pomocne w rozjaśnieniu otwierających się tu problemów. W istocie, gdy idzie o stanowisko krytyczne w odniesieniu do stoicyzmu - wszystko zostało już rozstrzygnięte: użycie tego terminu jest w pełni podporządkowane - już tutaj - nowej perspektywie. Wrócimy do tych kwestii, ale obecnie konieczne jest odrzucenie owych wyłącznie filologicznych pokrewieństw.

${ }^{6}$ Fragment listu Descartes'a do Mersenne’a z 25.11.1630 roku jest dostępny w języku polskim (Alquié 1989, 188).

${ }^{7}$ Świadectwa pracy nad tematami metafizycznymi, które miałyby się składać na Traité de la Divinité,znajduja się w: (AT I 17, 23, 137, 144, 350).
} 
Zatem metafizyka oddzielenia. O Traité de la Divinitê ${ }^{8}$ wiemy bardzo niewiele, jednak z tego, co wiemy, wynika, że sformułowana jest tam przede wszystkim krytyka bezpośredniości i dopełniające ja stwierdzenie radykalnej niepewności świata. Uniwersum renesansowe rozpada się na kawałki. Powszechna ciagłość zastępuje powszechna nieciagłość. Wszechrozległa konieczność świata renesansowego zastępuje radykalna przygodność. Odwrócenie nie mogło być pełniejsze. „Prawdy matematyczne, które nazywasz wiecznymi pisał Descartes do Mersenne’a - zostały ustanowione przez Boga i całkowicie od niego zależą, tak jak pozostałe stworzenia” (AT I $145^{9}$ ). Rozum, który rozpoznał siebie jako całkowicie zgodny i adekwatny w odniesieniu do kosmosu, teraz odkrywa się ponownie jako w pełni poddany woli całkowicie zewnętrznej, całkowicie transcendentnej. Prawdą nie jest kosmos, lecz władza, moc boska, która pieczętuje absolutną separację.

\begin{abstract}
Zapytujesz, Ojcze, in quo genere causae Deus disposuit aeternas veritates? [przez jaki rodzaj przyczynowości Bóg ustanowił prawdy wieczne] Odpowiem ci, że in eodem genere cause [przez ten sam rodzaj przyczynowości], przez jaki stworzył wszystko, czyli ut efficiens et totalis causa" [jako przyczyna spraw cza i całkowita]. Jakoż jest czymś niewattpliwym, że jest on stwórca zarówno istoty, jak istnienia stworzeń: otóż istota ta to nic innego, jak owe prawdy wieczne, które, tak jak ja to ujmuję, bynajmniej nie emanują z Boga niczym promienie słoneczne, wiem natomiast, że Bóg jest twórcą wszystkiego i że te prawdy są czymś, a zatem że jest on ich twórca. Powiadam, że wiem o tym, a nie, że pojmuję to czy rozumiem, można bowiem wiedzieć, że Bóg jest nieskończony i wszechmocny, chociaż nasza dusza nie może tego pojać czy zrozumieć, skoro sama jest skończona; podobnie możemy dotknąć ręką góry, lecz nie możemy jej objąc jak drzewa lub jakiejś innej rzeczy, która nie wykracza poza wielkość naszych ramion;
\end{abstract}

8 Baillet I, s. 170-171(Gilson 1930, 17-20,151-152), wysuwa hipotezę, że podłożem, z którego wyrasta metafizyka Descartesa, jest precyzyjnie już przeprowadzone wyjaśnienie podstawowych zasad fizyki, to znaczy mechanicyzm - stąd konieczność ustanowienia metafizycznych podstaw rozdzielenia duszy i ciała. Metafizyka Kartezjusza tworzyłaby w ten sposób continuum, osiagające najwyższą jasność w Szóstej Medytacji. Ta teza wydaje się w oczywisty sposób nie do przyjęcia. Gouhier (1951, 5-29) trafniej podkreśla dystans dzielący łaciński traktacik z 1629 roku od metafizyki Rozprany o metodzie i Medytacji. Gouthier kładzie nacisk na pogłębienie tej tematyki właśnie podług linii metafizycznej, zauważając w szczególności, że nieobecny jest tu moment kluczowy dla metafizyki dojrzałej, tj. dyskurs o watpliwości, cogito, interpretowanego w metafizycznej gęstości, która je wyodrębnia, nie zaś po prostu zgodnie z tradycją „uczonej niewiedzy” (s.11). Powiedziawszy to wszystko (i przyjąwszy, jak zwykle się to robi, że treść łacińskiego traktaciku odpowiada temu, co ujawnia list do Mersenne’a z roku 1630), trzeba jeszcze rozjaśnić rzeczywisty metafizyczny zasięg tego tekstu. Wydaje nam się - i będziemy do tego często wracać - że interpretacja F. Alquiégo (Alquié 1950)w szczególności 87-109, lepiej niż inne odpowiada rzeczywistości. W tym ujęciu Kartezjusz nie rozwija dyskursu komplementarnego wobec badań fizycznych, lecz utrzymuje na poziomie metafizycznym partykularne i absolutnie odrębne doświadczenie separacji (które będzie miało - ale w drugiej kolejności - reperkusje w planie fizyki). Teoria prawd wiecznych nie rodzi się z wymagań pracy fizyczno-matematycznej, lecz właśnie z zerwania z nimi. E. Bréhier zwraca uwage na osobliwość tego doświadczenia metafizycznego i jego znaczenie ontologiczne (ontologia oddzielenia), zob.(Bréhier 1937, 15-29).

${ }^{9}$ Fragment listu do Mersenne’a z 15.04.1630 roku jest dostępny w języku polskim (Alquié 1989, 184). 
albowiem pojąć to objąć myślą, wszelako na to, żeby coś wiedzieć, wystarczy dotknąć to myślą.

\begin{abstract}
Zapytujesz także, kto zmusił Boga do stworzenia tych prawd? A ja mówię na to, iż tak samo wolno było mu sprawić, aby nie było prawdą to, że wszystkie linie wyprowadzone ze środka okręgu są rów ne sobie, jak nie stwarzać wcale świata. I jest czymś niewątpliwym, że prawdy te są złączone $z$ jego istotą w sposób równie konieczny, co inne stworzenia. Pytasz, co Bóg uczynił, ażeby owe prawdy wytworzyć. Twierdzę, iż ex hocipso quod illas ab aeterno esse voluerit et intellexerit, illas creavit [przez to, że chciał je i pojmował odwiecznie, stworzył je), albo (jeżeli wyraz creavit odnosisz tylko do istnienia rzeczy] illas disposuit et fecit [ustanowił je i sprawił]. Albowiem w Bogu jest tą samą rzeczą chcieć, rozumieć i stwarzać, tak iż jedno nie poprzedza tu zgoła drugiego, ne quidem ratione [naw et logicznie)](AT I 151-152) ${ }^{10}$.
\end{abstract}

Oddzielenie jest tyleż radykalne, gdy idzie o intensywność, ile powszechne, gdy idzie o rozciagłość. Stwierdzenie przygodności wszelkiej istoty w odniesieniu do woli boskiej wydaje się odbierać światu jakakkolwiek realnośćc ${ }^{11}$. Powrócimy do tego później. Teraz trzeba przede wszystkim podkreślić, że związek między rzeczywistością a podmiotem jest tu pozbawiony jakiejkolwiek realności: jeśli się ustanawia, związek taki może być tylko punktowy, jak gdyby zawieszony nad radykalną nieciąłością rzeczywistości ${ }^{12}$. Usunięty zostaje przede wszystkim związek z przeszłością - jako pamięcią, jako cielesnym doświadczeniem kontaktu $\mathrm{z}$ rzeczywistością w perspektywie humanistycznego przywłaszczenia świata. I tak sama pamięć ze znaku rzeczywistości przekształca się w stan zasadniczo niepewny ${ }^{13}$. Rozwinięta w Studium bonae mentis krytyka bierności pamięci została umocowana na podstawach ontologicznych, które zniekształciły jej sens, zniszczyły sama najgłębsza strukturę ciagłości i wystawiły podmiotowość na wszelkie ryzyko samotniczego związku z oddzielonym światem. Perspektywa wyznaczona przez rozum: abducere mentem a sensibus, ani nie może, ani nie zamierza stanowić jakiegokolwiek rozwiązania. Przeciwnie, wskazuje po prostu nowy punkt widzenia, zgodnie z którym separacja nie zostaje przekroczona, lecz jeszcze bardziej uwypuklona: stąd kondycja dualistyczna i oddzielenie jawią się jako nierozwiązywalne. A jednocześnie owo wskazanie jest wynikiem doświadczenia,

\footnotetext{
${ }^{10}$ Fragment listu do Mersenne’a z 27.05.1630 jest dostępny w języku polskim (Alquié 1989, 187-188). Por. również ogólnie AT I 147-150.

11 Trzeba przywołać tu interpretację (Alquié 1950) jako komentarz i istotną pomoc w lekturze, zob. zwłaszcza s. 87-109.

12 Z najwyższą elegancją zilustrował tę sytuację J. Wahl w krótkiej pracy (Wahl 1953).

13 O pamięci jako żywiole fundamentalnej niepewności sądu, np. (AT I 22, 44), (AT IV, 114, 116, 117); (AT VII 4, 25, 70, 146), (AT X 387, 388, 408, 409, 515) etc.
} 
bezpośredniego odczucia tej sytuacji. Jak gdyby w mechanizm rozumu Descartes włączał I doprowadzał do najwyższego pobudzenia formę mistycznej procedury abstrahowania od świata. Rozumiemy, dlaczego Descartes deklaruje zbieżność z Bérullem i Gibieufem; ostatecznie w tematach Traité de la Divinité pobrzmiewa sytuacja duchowa, w której w całości odsłania się problem stulecia, a zatem i dyskusja, która domaga się powtórzeń, pogłębień i rozstrzygnięć w sporze: „Pozwolę sobie męczyć Pana, skoro tylko skończę mały traktat, który zaczynam”(AT I, 17). „W tym, co tyczy się wolności Boga, całkowicie podzielam opinię, która - jak mi Pan donosi - wyłożył ojciec Gibieuf' (AT I 15314). Ale to nie wszystko. Obaj, i Bérulle, i Gibieuf, negują możliwość pojęcia absolutu, objęcia go rozumem ${ }^{15}$. Negacja ta jest jednocześnie mistycznym napięciem, twierdzeniem metafizycznym i historyczną konfrontacja z pamięcia renesansową ${ }^{16}$ - oddzieleniem, które przechodzi przez wszystkie poziomy, obejmując ponownie właśnie całość sytuacji. Chyba nic nie zdołało lepiej niż owa konotacja religijna nadać znaczenia całemu oddziaływaniu kryzysu, w ramach którego porusza się myśl Descartesa: albowiem w tym stuleciu tyrańskiemu wpływowi uczuć religijnych często powierza się jeszcze uogólnienie przeżytego doświadczenia.

Samokrytyka pamięci, która dociera do zdefiniowania sytuacji ogólnej niepewności, uniwersalnej przygodności, powszechnego oddzielenia: oto szczególny moment myśli kartezjańskiej pod koniec lat 20. Horyzont scientia mirabilis, prometejska nadzieja pokładana w invenire i entuzjazm wynikający z renovatio wydają się znikać w nieokreślonej oddali: „... i kiedy tylko zobaczę słowo arcanum w jakiejkolwiek tezie, zaczynam być o niej złego zdania" (AT I 78). Żaden z tych tematów nie może zostać przywrócony pamięci, ponieważ ona sama zatraciła się w poprzerywanym i kruchym wymiarze czasowości. To odwrócenie całkowite, precyzyjne, wyraźne.

Trzeba je koniecznie rozpoznać, lecz to nie wystarczy. Skąd więc to odwrócenie? Ustalenie jego powodów będzie teraz naszym celem. Zanim jednak osiąniemy jasność w tej kwestii, warto jeszcze podkreślić bogactwo implikacji. Od krytyki pamięci do odwrócenia perspektywy metafizycznej - o tym była mowa, ale przemierza się również drogę odwrotną od oddzielenia ufundowanego w porządku metafizycznym do oddzielenia w porządku historycznym. Radykalna przygodność odkryta w odniesieniach teologicznych rozprzestrzenia się natychmiast na odniesienia historyczne, w świecie społecznym powtarzają się podstawowe

14 Zob. również AT I 220.W kwestii wpływu Bérulle’a i ogólniej Oratorium na Descartesa, zob. (Gilson 1913, 27-50), (Gouhier 1924, 57 i n.), (Gilson 1930, 33-36, 289).

15 O różnicy między pojmowaniem (intendere) i rozumieniem (comprendere) u Bérulle'a, zob. (Dagens 1952). Na s. 257 Dagens konkluduje: „ta różnica jest fundamentalna i dostrzegamy tu jedno z najściślejszych powiązań między myślą Bérulle’a i Descartesa”. Jasno dostrzega też ten punkt J. Orcibal (1965), szczególnie w związku $\mathrm{z}$ teorią ciagłego stwarzania.

16 W pierwszej części (1-77) cytowanej pracy J. Dagens wskazuje, jak głęboko krytycyzm myśli Bérulle’a i jego szkoły zakorzeniony jest w kulturze renesansu. 
cechy przygodności. Nie powinno nas to dziwić. Widzieliśmy, że w świecie metafory istnieje pewien rodzaj jednolitej zwartości, konwergencji wszystkich aspektów doświadczenia. Teraz, właśnie w tej mierze, w jakiej ów wszechświat był zwarty, powszechny staje się kryzys. Oddzielenie ustanawia się z taką samą intensywnością w świecie i w sferze społecznej. Widać, jak teoria tworzenia wiecznych prawd, na której funduje się radykalny wysiłek uczynienia wszechświata przygodnym, zyskuje natychmiastowe egzemplifikacje: prawda zostaje ustanowiona przez Boga niczym prawo absolutnego suwerena, obowiązywanie prawa zawierzone zostaje mocy, która je podtrzymuje, a moc ta jest niepojęta w swym pochodzeniu i pobudkach:

Błagam Cię, Ojcze, śmiało i bez obaw zapewniaj wszystkich i wszędzie rozgłaszaj, że to Bóg ustanowił te prawa w przyrodzie, tak jak król ustanawia prawa w swoim królestwie.

Nie ma pośród nich takiego, którego byśmy nie mogli pojąć, gdy umysł nasz jest skłonny je rozpatrzeć, i wszystkie sa mentibus nostris ingenitae [wrodzone naszemu umysłowi] na tę samą modłę, na jaką król wyryłby swoje prawa w sercach swych poddanych, gdyby miał po temu odpowiednią władzę. Przeciwnie, nie możemy pojąc wielkości Boga, mimo że ją znamy. Jednak już to samo, że uważamy ją za niepojęta, każe nam tym wyżej ją cenić; podobnie król ma tym więcej majestatu, im mniej są obeznani z nim jego poddani, byle tylko nie myśleli przez to o nieistnieniu nad soba króla i znali go wystarczająco dla rozproszenia tych wątpliwości. Powie ci ktoś, że gdyby Bóg ustanowił owe prawdy, to mógłby je zmieniać tak, jak to król robi ze swymi prawami, na co należy odpowiedzieć, że owszem, jeśli jego wola może się odmienić. - Ale ja ujmuję je jako wieczne i niezmienne. A ja sądzę to samo o Bogu. Lecz jego wola jest wolna. - Owszem, wszelako jego moc jest niepojęta; toteż w ogólności możemy mieć tę pewność, że Bóg może uczynić wszystko, co my możemy pojać, lecz nie tę, że nie może zrobić tego, czego sami pojąć nie możemy, zuchwalstwem byłaby bowiem myśl, że wyobraźnia nasza ma ten sam zasięg, co jego $\operatorname{moc}($ AT I 145-14617).

Lecz w takim razie - wszystko co łączy, jest zarazem składnikiem oddzielenia, transcendencja w jednorodny sposób kwalifikuje każdą relację między podmiotem i światem. Czym jest zatem świat? Widmem, nad którym ciąży niepojęta wola suwerena. Oto odwrócony obraz, do którego dochodzi Descartes. Gdzie podziała się laetitia [radość] spełnionego związku z tym, co rzeczywiste, ufność, że rzeczywistość odpowiada podmiotowi, wiara w źródłowa i konieczną zbieżność, w której poruszają się podmiot i świat? „Natura - pisał Galileusz drwi sobie z postanowień i dekretów książąt, imperatorów, czy monarchów, których żądania

\footnotetext{
${ }^{17}$ Fragment listu do Mersenne’a z 15 IV 1630 jest dostępny w języku polskim (Alquié 1989, 184-185).
} 
nie zmieniają ani o jotę jej praw i statutów"18. Tu ludzka cnota znajduje swe uniwersalne potwierdzenie i realizację bez żadnego rodzaju mediacji. Jeszcze niedawno Descartes mógł podpisać się pod tym twierdzeniem. Teraz wszakże wola suwerena rozciaga się nad rzeczami, a władza drwi sobie z natury.

Dlaczego jednak mieszczańska nadzieja na szczęśliwy podbój świata została poddana krytyce i porzucona? Dlaczego humanistyczna wiara w możliwość przywłaszczenia świata uległa zniszczeniu? Skąd to odwrócenie?

\section{2.}

Radykalizm, intensywność, całościowy charakter implikacji sprawia, że odwrócenie stanowiska kartezjańskiego pod koniec lat 20. budzi zakłopotanie. Owa zmiana nie znajduje uzasadnienia we wcześniejszym rozwoju myśli Descartesa. Jeśli w jej pierwszej fazie, w dyskusji z najbardziej rozbuchanymi stanowiskami renesansowymi, nie brakowało zalążków krytycznych, zmierzały one, jak widzieliśmy, ku wyodrębnieniu, a dalej odnowieniu, lub w każdym razie pobudzeniu momentu humanistycznego, stanowiącego inspirację owych najdalej idacych konsekwencji. Miraculom [cudom] filozof przeciwstawiał scientia mirabilis: albowiem intuicja filozoficzna opierała się na solidnym posiadaniu świata, wiedza zaś na ufności w zgodność naukii rzeczywistości, na pewnym nabyciu doświadczenia renesansowego. Czy więc ta zmiana, nieuzasadniona teoretycznie, może być wyjaśniona historycznie? Wskazywałby na to już jej charakter formalny: nagły i głęboki kryzys, niespodziewany wpływ katastrofy obejmującej podmioty, które jej nie wywołały, jakkolwiek zostały w nią radykalnie włączone. Tylko kryzys zbiorowy, wiążący indywidua, może - jak się wydaje - stanowić rację kartezjańskiej zmiany. A zatem kryzys kartezjański jest w istocie kryzysem całego stulecia, indywidualnym aspektem kolektywnego dramatu.

Od pewnego już czasu ,wielki wiek” nie jest przez historiografię przedstawiany jako czas złotej stabilizacji, opiewanej przez pewną tradycję apologetyczną. Przeciwnie, to wiek bogaty w różnorodne dramatyczne wydarzenia, głębokie walki, pośród których wszelka równowaga polityczna i kulturalna znalazła się w kryzysie i jedynie z wielkim wysiłkiem dawała się odbudować19. Lecz nie wystarczy podkreślić niestabilność stulecia: badania

\footnotetext{
18 Cytowane w: (Garin 1965, 155).

19 Jeszcze raz pozwalamy sobie odesłać do naszego przeglądu bibliograficznego (Negri 1967, 183-220). Bogata bibliografia przedmiotu (przede wszystkim taka, którą można określić mianem „rewizjonistycznej”) została tam zebrana, omówiona i uporządkowana.
} 
historyczne wyróżniły też szczególne momenty owego kryzysu, koniunktury ${ }^{20}$ najbardziej charakterystyczne i kluczowe dla tego wieku. Od niedawna uwaga zatrzymuje się bez wattpienia na dziesięcioleciu następującym po roku 1619, by wskazać jeden z najbardziej znaczących momentów koniunktury, a raczej centralny punkt tej koniunktury, w ramach której nie tylko ukazuje się „cezura między wiekami”, prawdziwy i właściwy początek wieku XVII jako epoki w dziejach Europejczyków, lecz nade wszystko wyłania się „styl” charakterystyczny dla tego stulecia. W kryzysie gospodarczym lat 1619-1622, dodaje historyk, wyczerpały się wielkie, kapitalistyczne nadzieje XVI wieku. Ów długi okres, na który przypadł rozwój gospodarczy i obywatelski renesansowego kupiectwa, miał się ku końcowi²1. A zatem zła koniunktura gospodarcza, ale nie tylko. Oto kryzys dotyka cały trend rozwojowy XV i XVI wieku, wraz z najgłębszymi pobudzającymi go pierwiastkami, wraz z napięciem, które od działalności gospodarczej wiodło ku heroicznej odbudowie świata. A jednak odkąd owa nadzieja humanistyczna stała się substancją historyczna, nieusuwalnym elementem rozwoju europejskiej świadomości, nie mogła już nigdy popaść w zapomnienie. Kryzys rozwijał się więc wewnątrz struktury, nie zrywając ciągłości humanizmu ${ }^{22}$. Nie był przez to mniej bolesny czy mniej dotkliwy. W istocie zmienia się styl epoki: poczucie klęski, stanu oddzielenia, w którym nowy człowiek zmuszony jest teraz żyć, pogrążony w nostalgii za rewolucyjną pełnią humanistycznego i renesansowego rozwoju, lecz już pochwycony przez kryzysowa konieczność. $\mathrm{Na}$ „barok” składa się zapewne napięcie między świadomością ciężkiej, nieubłaganej porażki a ujawniającą się wciąż na nowo nostalgią za tamtym doświadczeniem. Niektórzy trafnie określili stabilizującą się i rozprzestrzeniającą w tej sytuacji mentalność jako „patetyczna”, inni - także bardzo słusznie - kładli nacisk na nadzwyczajny wpływ, jaki kryzys ten wywarł na wszystkie aspekty życia kulturalnego i obywatelskiego ${ }^{23}$. W każdym razie zachowana zostaje relacja ciagłość-zerwanie: zerwanie tym bardziej bolesne, im silniej odczuwana jest ciągłość, przeszłość zaś - przypominana z nostalgią ${ }^{24}$.

20 Włoskie słowo congiuntura pojawia się w tekście w dwóch znaczeniach: „koniunktura” i „połączenie”. W przekładzie tytułu zdecydowano się na pierwsze, jako istotniejsze dla publikowanego fragmentu [przyp. thum.].

21 (Romano 1962, 480-531) Bardziej ogólnie, zob. też (Aston 1965), zwłaszcza eseje E.J. Hobsbawma (5-58) i H.R. Trevor-Ropera (59-95).

22 „Wiek humanizmu” biegłby „w literaturze od Petrarki do Goethego, w historii kościoła od schizmy na Zachodzie do sekularyzacji, w historii społeczno-ekonomicznej od komun miejskichi prekapitalizmu handlowego do rewolucji przemysłowej, w historii politycznej od śmierci cesarza Karola IV do rewolucji francuskiej" (Cantimori 1959, 361) (lecz zob. także Cantimori 1959b, 366-378). Trzeba wyraźnie podkreślić, że wiek XVII winien być definiowany w ścisłej w ciagłości z tym, co wcześniejsze i tym, co późniejsze: nie jest zerwaniem, lecz kryzysem wzrostu, przeobrażeniem, nowym zorganizowaniem problemów wyrosłych już wcześniej.

23 Zob. (Braudel 1953, 830) [1976-1977]. Lecz przede wszystkim (Mandrou 1960, 898-914).

24 (Adam 1949, 208-224); (Bonfantini 1964, zwłaszcza 17 i n., 89 i n., 105 i n.). 
Jakie sa jednak przyczyny kryzysu, szczególnie zaś owego gwałtownego wybuchu w koniunkturze lat 20.? Wspominaliśmy już o tym: to kryzys pierwszego rozwoju kapitalistycznego (kapitalizmu, rzecz jasna, przede wszystkim handlowego), kryzys wszystkich związanych z tym rozwojem pierwiastków politycznych i kulturalnych. A zatem kryzys mieszczańskiej wolności, w tej mierze, w jakiej miała odbudować świat, zarówno świat gospodarczy, jak religijny i polityczny - każdy z nich odniesiony do wymiaru ludzkiego, jako makrokosmos stanowiący jakościową kontynuację ludzkiego mikrokosmosu. To kryzys indywidualnej wolności - pierwszego heroicznego i historycznie znaczącego przejawu indywidualności, w której, w swoim złożonym rozwoju, całe społeczeństwo spodziewało się znaleźć domknięcie i całościową odnowę, mając za swoją miarę wolność indywidualną. Tę wzniosłą nadzieję wyraża zarówno egzemplaryzm filozoficzny, jak i mistyczny egzemplaryzm renovatio, zarówno naukowy uniwersalizm, jak i techniczny prometeizm. Również sam matematyzm wpisuje się w ten teoretyczny i praktyczny horyzont. Choć ujmuje go teoretycznie, służy jego reprodukcji - stąd pojawienie się manufakturowego sposobu produkcji ${ }^{25}$. Kryzys obejmuje więc wszystkie te elementy: nie tyle (w każdym razie nie jest to czynnik zasadniczy) dlatego, że ścieraja się one ze starożytnym obrazem świata i z organizującymi się wokół niego siłami, ile dlatego, że wolność zderza się ze skutkami swego własnego rozwoju. Dzieje się to w planie kulturowym, religijnym i obywatelskim wszędzie jednoczący wymóg propozycji humanistycznej prowadzi, paradoksalnie, do rozdzielenia. Przede wszystkim zaś ma to miejsce w planie ekonomicznym, gdzie rozwój gospodarki monetarnej (koniecznej formy uspołeczniania indywidualnych działań na rynku) objawia się poprzez mechanizmy, które zaburzają każdy stan równowagi i ukazuja utopijny charakter projektowanego powrotu - homogenicznego - od tego co, indywidualne do tego, co kolektywne. Właśnie w planie ekonomicznym dostrzeżenie owej straszliwej niestabilności wymusza refleksję o powszechnym charakterze kryzysu: kryzysu burżuazji, która zmuszona jest zrezygnować - jakby obnażono jej iluzje - z rozpoznawania w sobie samej ogólnego interesu społecznego. Burżuazja musi się zatem wycofać i porzucić żądanie władzy nad całym społeczeństwem. Zobaczymy, jaki kształt to przyjmie. Teraz wystarczy zauważyć, że kryzys, który zaczął się w 1619 roku, stanowi moment domykający proces pogłębiania krytycznej świadomości rozwoju: ów moment przejawia się w zmęczeniu postępującym kryzysem monetarnym, w zaniepokojeniu rozpoczynającą się właśnie wojną europejską. Przede wszystkim jednak jest to moment, w którym burżuazja odczuwa wreszcie nacisk walk prowadzonych przez nowe klasy, ukształtowane i ograniczane przez jej własny rozwój:

\footnotetext{
25 O tej złożonej tematyce, zob. (Von Martin1951, 37-64). Zob. też cytowaną wyżej pracę (Borkenau 1934), oraz tegoż (Von Martin 1932).
} 
wystapienia chłopskie i proletariackie następuja jedno po drugim ${ }^{26}$, ujawniając rozmiar konsekwencji określonych przez rozwój i jego obecny kryzys, przez ogólną przebudowę stosunków między klasami i przez upadek burżuazyjnego projektu związania ich w nowym porządku. Sytuacja osiaga granicę przewrotu: nowego porządku, którego burżuazja nie była w stanie zaprowadzić, lub też który ukazała jako rewers daleko cięższego kryzysu, domaga się obecnie kto inny, ustanawiaja go nowe sily rewolucyjne. W tej nowej sytuacji pierwsze zdobycze burżuazji moga zostać zniszczone lub zagrożone. Czy dziwi zatem, że w wypadku burżuazji poszukiwanie bezpieczeństwa zastępuje dawną nadzieję? Że w obliczu kryzysu, wywołanego jej własnym rozwojem, burżuazja odpowiada zanegowaniem najdalej idących konsekwencji swych nadziei i żądaniem w zamian gwarancji tego, co osiągnęła? ${ }^{27}$ Oto czym jest definitywny i ciężki kryzys trzeciego dziesięciolecia XVII wieku: świadomość końca epoki rewolucyjnej, odwrócenie tendencji, kumulatywne złączenie [congiuntura] wszystkich momentów kryzysu, by umocować go w strukturze stulecia.

Kryzys lat 20. ma charakter podsumowania i kumulacji, co daje się potwierdzić również w jego wymiarze kulturowym. W szczególności motywy sceptyckie i libertyńskie które od momentu pęknięcia kulturowej i religijnej jednomyślności Europy raz po raz powracają, stanowiąc zapis krytycznej sytuacji- ulegają restrukturyzacji i osiagaja skrajną intensywność. Jeśli istnieje w historii myśli moment, w którym rozpoznać można jakościowy skok ponad i poza tradycję, to właśnie go analizujemy (Tenenti 1963, 1-19). Doświadczenie końca świata renesansowego urzeczywistnia się tu, w wyrazie zbiorowym, jako poczucie oddzielenia - postrzegane i doświadczane jako historyczne przeznaczenie. Libertynizm zaś, wraz ze swymi motywami sceptyckimi i bluźnierczymi, jest pierwszym znaczącym wyrazem nowej sytuacji28. Tu poczucie oddzielenia jest największe: renesansowe życie, polityczne

26 W tej bardzo ważnej kwestii pozwalamy sobie odesłać do naszych(Negri 1967)i innych odnotowanych w niej prac: w szczególności: (Porchnev 1963); (Mousnier 1958, 81-113);(Mandrou 1959, 756-765);(Vivanti 1964,957-981).

27 Także w tej kwestii pozwalamy sobie odesłać do przypisów oraz dzieł omówionych przez nas w pracy przeglądowej: (Negri 1967).Użytecznego przykładu, obrazującego wewnętrzny charakter kryzysu, dostarcza prześledzenie dialektyki cnoty i losu (virtù-fortuna) w jej nierozstrzygalności - najpierw w refleksji humanistycznej, następnie w europejskiej myśli renesansowej. W tej kwestii zob. piękną uwagę E. Garina (1965, 53): „Nad tym wszystkim dominowała humanistyczna wiara w człowieka, w jego rozum, w jego zdolność budowania: homo faber jako twórca samego siebie i własnego losu. Tego jednak, kto prześledzi pisma czternastowieczne, uderzy właśnie to, jak zmienia się opracowanie tematu fortuny: jak rozszerza się jej królestwo, jak rośnie brak wiary w ludzkie możliwości i poczucie, że nawet doskonałe miasta świata starożytnego rozpadly się w końcu za jej sprawą. To właśnie tyche niszczy nawet państwo Platona; mędrcowi pozostaje jedynie namysł nad przyczynami upadku Rzymu...”. A zatem virtù i fortuna. Lecz fortuna, która wcześniej stanowiła potwierdzenie cnoty, zrealizowanej wolności - później ujawnia się jako moc zewnętrzna, przeciwna wolności... Ta dialektyka właściwa jest narodzinom kapitalizmu, ale też znajdziemy ją uogólnioną na przestrzeni całego jego istnienia. Tutaj, w źródłowym momencie kultury burżuazyjnej, objawia się z najwyżs za jasnościa.

28 (Busson 1933); (Pintard 1943); (Adam1935); a także (Adam 1964); (Spink 1960) [1974]; (Popkin 1964). O libertynach w kontekście kryzysu myśli renesansowej, zob. (Febvre 1957, 337-358). 
i obywatelskie nadzieje humanizmu, naukowa żądza pojęcia świata jako całości - zawodzą i zostaja poddane radykalnej krytyce. Ale tęsknota za tymi ideałami pozostaje wśród libertynów żywa: stąd oddzielenie jest odczuwane dramatycznie, miałoby bowiem przenikać czyniąc go irracjonalnym i nieosiąalnym - wewnętrzny proces, poprzez który urzeczywistnia się wszelki ideał. Pozbawiony renesansowej nadziei, świat stał się czymś nad wyraz niepewnym, czemu przeciwstawia się - jak gdyby podkreślając ową niepewność - tęsknotę, świadomą tęsknotę, za dawnymi ideałami. Nietrudno w tej sytuacji przejść od tęsknoty do utopii! A rezultaty tego ruchu ukażą w sposób jawny to, co od zawsze było w tym ruchu zawarte implicite ${ }^{29}$. Lecz teraz, w początkowej fazie rozwoju libertynizmu, w ruchu dominuje przede wszystkim poczucie oddzielenia: to oddzielenie od masywnej zwartości renesansowego obrazu życia i nauki, ale również psychologiczna, subiektywna, izolacja od życia obywatelskiego. Czy lepiej: można nawet się w nim zanurzyć, zawiesza się jednak osąd, izoluje się namiętność, przeciwstawiając ją uczestnictwu i komunikacji, uwalnia się ideał przeżywając go w oddzieleniu i uznając za nierealizowalną utopię - od pokusy przekształcenia go w ideał zbiorowy. Stając się bowiem ideałem zbiorowym, mógłby jedynie ponownie rozwinąc tę niszcząca moc, której doświadczono już kiedy indziej. Po klęsce się nie wraca, lepiej nie próbować powrotu ${ }^{30}$. Mądrość jako społeczny konformizm jest tylko wolnościa wewnętrzną: foris ut moris, intus ut lubet! [na zewnątrz zgodnie z obyczajem, u siebie - jak nam się podoba]. Nadzwyczajne powodzenie Charrona w całości wyraża się w poradach, by oddzielić mądrość od wszelkich projektów uniwersalizujących (w teorii) i rewolucyjnych $(\text { w praktyce })^{31}$.

Tematyka libertyńskiej myśli i praktyki ostatecznie organizuje się i ujawnia ze szczególną intensywnością w momencie politycznego namysłu nad kryzysem: ponownie wyeksponowany zostaje tu ogólny motyw oddzielenia, rozpatrywany w ramach politycznego rozwoju społeczeństwa francuskiego i powiązany ze szczególnego rodzaju rozstrzygnięciem. $\mathrm{Na}$ innych polach, wobec innych doświadczeń, odmowa, wybór negatywny mogą zatrzymać się w negatywności. Ale nie w polityce, gdzie wybór negatywny nadal pozostaje wyborem,

${ }^{29}$ Szczególny nacisk na owo przejście do utopii kładzie A. Adam w Préface [Przedmowie]do:(Adam 1964). Zob. również (Vivanti 1963, passim). Utopistyczne roszczenia będą wszakże wyrażane szeroko przede wszystkim w drugiej połowie wieku.

30 Odsyłamy ponownie do naszej pracy (Negri 1967).

31 O powodzeniu Charrona, zob. (Lenoble 1943, 44-45); (Busson 1933, 47 i n., 73 i n., 181 i n.). Ostatnio, oprócz (Tenenti 1963, 12-18), zob. (Baron 1960, 131-150), który doskonale uwypuklił krytyczną treść Charronowskiego ideału mądrości, przeciw tezom wysuniętym w skądinąd ważnym dziele E.J. Rice'a (Rice 1958, zwłaszcza 214 i n.). Baron (podobnie jak z innej strony Garin 1965, 117-118) przeciwstawia tym, którzy ujmują ów zasadniczy moment krytyczny w terminach pozytywnych (i ustanawiają w ten sposób ciągłość między libertynizmem i wiekiem świateł), negatywność owej krytycznej treści, zawartej w zarysowanej przez Charrona i rozwiniętej przez libertynów koncepcji wiedzy. Nie trzeba zaznaczać, że całkowicie zgadzamy się z tą interpretacją. Nie przeczy ona, że - w całej swej negatywności - zarysowana tutaj koncepcja wiedzy utrzymuje ton fundamentalnie „społeczny”: „Francuskie wolnomyślicielstwo było zawsze w swej istocie społeczne" (Spink 1960, 5). 
nieuniknioną decyzją w odniesieniu do bytu społecznego. Libertyńskie poczucie oddzielenia, powołanie do odosobnienia, musi się więc tu ukazać z najwyższą intensywnością, w sposób emblematyczny dla innych motywów tej myśli, odsłaniając jej motyw źródłowy. Oddzielenie jest tu zatem oddzieleniem społeczeństwa obywatelskiego od państwa - zapisem porażki humanistycznego projektu rekompozycji jednego w drugim. Z rozpoznania tego odłączenia wywodzi się libertyńska akceptacja nowej struktury politycznej i państwowej - nowego absolutyzmu - jako pozytywnej decyzji, wynikającej z odmowy: absolutyzm jest bowiem teraz jedynym układem, wewnątrz którego odmowa politycznego uczestnictwa zapewnia ograniczona, ale bezpieczną przestrzeń społeczna, gdzie można zdobyć sobie wyizolowaną rozkosz wolności - nostalgiczny renesansowy sen, kultywowany w odosobnieniu, przez ograniczone grupy wybranych, wreszcie uwolnionych od możliwości przekształcenia tego snu w zbiorowe narzędzie przewrotu. Ideologiczna lekcja wojen religijnych, precyzyjnie sformułowana przez Bodina, zostaje teraz podjęta: teoria staje się życiem, mądrościa życia w oddzieleniu ${ }^{32}$.

Oto więc środowisko, atmosfera, stanowiące punkt odniesienia dla poczucia zrozpaczonego oddzielenia, do którego myśl kartezjańska dociera u progu lat 30. Zmiana kartezjańskiego horyzontu filozoficznego jest ściśle powiązana z tą koniunkturą historyczną. A zatem barokowy Kartezjusz? Z pewnością, jeśli przyjmiemy szersze znaczenie terminu „barok”, „epoka baroku”: epoka refleksji, najwyższego napięcia wobec świadomości upadku renesansowego mitu ${ }^{33}$. I jeszcze: Descartes libertyn? Tu wywód staje się bardziej złożony. Z jednej strony, rzeczywiście, właśnie w owych latach, około roku 1630, znajdujemy u Descartesa serię motywów i, przede wszystkim, styl życia, które zdają się doskonale odtwarzać laicki ascetyzm libertyna: „Lękam się sławy bardziej niż jej pragnę, sądzę bowiem, że pomniejsza ona w pewien sposób wolność i czas wolny tych, którzy ją zdobywają, te zaś dwie rzeczy posiadam tak doskonale i cenię tak wysoko, że nie ma na Świecie Monarchy wystarczająco bogatego, by je ode mnie kupić" (AT I 136). Odkrywamy również motywy sceptyckie, naznaczone pyrronizmem, głęboko antyhumanistyczne - i właśnie towarzyszowi walk humanistycznych, Beeckmanowi, od którego ostatecznie się zdystansuje, Descartes musi koniecznie powiedzieć o swojej nieufności wobec filozofii: „Platon mówi jedno, Arystoteles drugie, Telesio, Campanella, Bruno, Basson, Vanini i wszyscy nowatorzy, każdy mówi co

32 O powodzeniu Bodina w początkach XVII wieku, zob.(Lenoble 1943,43); (Lecler1955,153-159) [1964] (dokumentuje, w szczególności, krążenie rękopiśmiennych kopii Heptaplomeres w tym okresie); (Von Albertini 1951, 35-37); (Church1941); (Picot 1948). (Tenenti 1963, 9-11, uwypuklił we wzorcowy sposób związek między myślą polityczną i racjonalizmem teologicznym u Bodina na tle kryzysu wywołanego wojnami religijnymi. Zob. również (Busson1957, 540 i n.). Rozwój ku politycznemu absolutyzmowi w sytuacji kryzysu kulturowego, który rozpoczyna się wraz z wojnami religijnymi, dopełnia zaś w koniunkturze gospodarczej XVII stulecia, jest zresztą udokumentowany przez wiele innych źródeł: zob. np. teksty i komentarze w (Bontems 1965), zwłaszcza artykuł Bontemsa.

33 Zob. rozważania i bibliografię dotyczącą tego tematu w: (Hagmann 1955, 17-25). 
innego". Nie dotyczy to tylko filozofii klasycznej i tradycyjnej, lecz także filozofii nowej: „Nie nauczyłem się nigdy niczego z pańskiej zmyślonej fizyki, którą określa pan mianem fizyki matematycznej, tak jak nie nauczyłem się niczego z Batrachomyomachii” ${ }^{34}$. Ostatecznie u Descartesa znajdujemy w tym czasie przede wszystkim ów mélange krytycznego radykalizmu oraz napięć mistycznych i pozytywistycznych, który posłuży do ataku na świat renesansowy, sprowadzony do niepewnego horyzontu, pozbawiony wszelkiej konieczności - tak, by ostał się jedynie społeczny konformizm i rodzaj surowej etyczności, zakorzenionej w pozytywności normatywnego uniwersum. To samo nastawienie znaleźć można u Charrona, do którego Descartes jawnie się odwołuje, u Guya Patina, Gabriela Naudé i innych libertynów ${ }^{35}$. A jednak, nieprzypadkowym zbiegiem okoliczności właśnie w tych listach, w których uwypuklił poczucie oddzielenia i głosił dramatyczną niepewność, w nich właśnie pojawia się pierwszy atak na pozycje libertyńskie. To listy z 15 kwietnia i 6 maja 1630 roku: kluczowy moment, gdy zarysowana zostaje kartezjańska doktryna prawd wiecznych. Oto, w tych właśnie listach, odnosząc się do wezwania Mersenne’a, Descartes zgadza się wyjść sur-le-champ przeciw un méchant livre [nikczemnej książce], która krążyła w ledwie 30-35 egzemplarzach i sam Descartes musiał czekać ponad rok, zanim ja mógł przejrzeć (AT I 144-145, 148-149, 181, 220) - przeciw un méchant livre (być może był to dialog Sur la Divinité La Mothe le Vayera ${ }^{36}$, gdzie przeczy się możliwości logicznego udowodnienia istnienia Boga. Tu atak Descartesa na myśli libertyńską nie zatrzymuje się, lecz rozszerza na dalszy tok jego dzieła, nawet niepotrzebnie, skoro pozycje libertyńskie niemal całkiem wyjdą z obiegu ${ }^{37}$.

34 Fragmenty te pochodzą z listu z 17 października 1630 roku, wyznaczającego moment zerwania Descartesa z Beeckmanem (AT I 156-170). Lecz o tej ostatniej fazie sporu dwóch dawnych współpracowników por. również: (AT I 154-156, 170 i n., 177 i n.). Chodzi tu niewątpliwie o argumenty sceptyckie - Descartes sam przyznaje: „niegdyś zetknąłem się z dość wielką ilością ksiąg [...\} napisanych przez akademików i sceptyków” (AT VII 130, Odpowiedź na z̧arzuty drugie; zob. w: (Descartes 1958, 165). Z drugiej strony widać, jak - w kontrze do pozycji kartezjańskich - u Beeckmana z coraz większą klarownością wyodrębnia się źródłowa treść mechanistyczna (z którą współbrzmią wątki atomistyczne, epikurejskie i częściowo sceptycyckie, towarzyszące często tej doktrynie): zob. (Gregory 1961, 133-134).

35 Odwołania do politycznego konformizmu Charrona w: AT VI 14, 16, 22 (por. Gilson, 1925, 173-174, 179, 235). Inne odwołania obecne u Descartesa i dotyczące Charronowskiej teorii dotyczącej zwierząt: (AT VI 58-59) i (AT IV 575). O całej tej kwestii zob. także: (Sirven 1930, 259-273). Stanowisko konformistyczne jest więc zdecydowanie libertyńskie. Spośród ogromnej liczby tekstów trudno dokonać wyboru: por.(Adam 1964), w szczególności rozważania snute wokół postaci Guya Patina (i jego słynnego listu do syna: audi, vide, tace, si vis vivere in pace [słuchaj, patrz, milcz, jeśli chcesz żyć w spokoju]). Analogiczna postawa u Naudé: zob. (Spink 1960, 20-21). W tej kwestii należałoby przyjrzeć się związkom (lub wpływom) łączącym Kartezjusza z myślą Sancheza i Cherbury'ego, z tym, co określa się jako konstruktywny sceptycyzm u Sancheza i dogmatyzm wia ry u Cherbury'ego: zob. często nazbyt wymyślne uwagi w: (Popkin 1964 38-43, 155-165).

36 Taką identyfikacje proponuje (Pintard 1937, 120-122). Ogólnie o stanowisku Le Mothe'a i twierdzeniach przedstawionych w De la Divinité (zob. wydanie Tisseranda, Paris 1922, s. 94 i n.), por. (Adam 1964121 i n.); (Spink 1960,18).

37 AT II 144; III 207; IV 187-188, 346 itd. Należy jednak przypomnieć, że w Liściedo dziekana i doktoróm fakultetu paryskiej teologii Descartes przedstawia Medytacje jako dzieło skierowane przeciwko libertynom (AT VII 2, 6). Zauważmy też, z jakim oburzeniem Descartes odpowiada na insynuacje-oskarżenia Voëta, że ,jest nowym Vaninim” (AT VIII B 169, 207, 210, 254). 
Jak interpretować tę sytuację? Pojawia się podejrzenie, że - przynajmniej w przypadku polemiki z książką La Mothe'a - mamy do czynienia z bardzo powierzchownym akcesem Descartesa do wspieranego przez Mersenne’a ${ }^{38}$ programu polemiki antylibertyńskiej. Być możechodziło o ukrycie dużo głębszego zaangażowania w problemową krytykę libertynizmu. Pozwala tak sądzić i ironiczny rys w metaforze owej walki, do której Descartes poczuł się zawezwany, i wesoły polemiczny cynizm, który skłonił Descartesa najpierw do twierdzenia, że jest rzeczą konieczną natychmiastowe przekazanie autora „nikczemnej książki” policji, następnie zaś do propozycji, by zmusić autora, aby samwłączył przedstawione obiekcje do swego tekstu (AT I 148-149) ${ }^{39}$. Tym niemniej sprzeczność istnieje, zajmuje precyzyjnie określone miejsce w rozwoju myśli Descartesa i w tym właśnie świetle zostanie wyjaśniona. Jakkolwiek Descartes rzeczywiście zgadza się z libertynami tam, gdzie ujawniaja kryzys świata renesansowego, gdzie stwierdzają stan radykalnego oddzielenia, w którym przyszło człowiekowi dzisiaj żyć, to przecież także problematyzuje tę sytuację: cały dalszy rozwój jego myśli będzie nakierowany na określenie negatywnych warunków oddzielenia, lecz także na określenie pozytywnych warunków rekonstrukcji. Descartes przyjmuje zatem libertyńskie rozpoznanie sytuacji i około roku 1630 jest, w opisanym wyżej sensie, prawdziwym libertynem. Do tego stopnia wpływa na niego koniunktura, naznaczając w ściśle określony sposób jego myśl. A jednak Descartes wzbrania się, teraz spontanicznie, później coraz bardziej świadomie i skutecznie, przed przyjęciem, że ta sytuacja miałaby być trwała, przed rozważaniem jej jako ostatecznej ${ }^{40}$. Dzieje się tak, ponieważ w sytuacji oddzielenia, opisanej poprzez teorię stworzenia prawd wiecznych, humanistyczna nostalgia próbuje ponownie otworzyć się - inaczej niż dzieje się to pośród libertynów - na nadzieję. Jakkolwiek jest prawda, że w horyzoncie metafizycznym wszelka konieczność została usunięta, wszelka uniwersalna korespondencja zanegowana, człowiek zaś został zawieszony nad radykalną przygodnością wszystkiego, to przecież boskość panuje nad światem jako obraz wolności i produkcji, jako aluzja i wymaganie innych horyzontów wolności. Przemieszczony w Boga, umocowany w niepoznawalnym, wolny byt jest jednak dany: w tym momencie głębokiego

38 Polemika z libertynizmem jest jednym z podstawowych składników działalności Mersenne’a:(Lenoble 1943, 168-199). O stanowiskach innych apologetów antylibertyńskich, w szczególności Garasse’a, por. (Adam 1964, 33-50).

39 Oczywiście nie chcemy tutaj przystać na obraz „Descartesa, filozofa w masce” (Descartes, le philosophe au masque), który tak sugestywnie, lecz również z wielką brawura, nakreślił swoim czasie Maxime Leroy (Leroy 1920). Zbliżenie Descartesa do libertynów jest dla nas raczej faktem obiektywnym, przykrą konsekwencją, nie zaś faktem subiektywnym; Leroy natomiast dochodzi do wniosków dokładnie przeciwnych.

40 Tym, co charakteryzuje libertynizm jest nie tyle samo uznanie oddzielenia, ile statyczny, definitywny charakter owego uznania: z najwyższą elegancją wyjaśnił to R. Popkin (1964, zwłaszcza 89-112), analizując całościowy sceptycki wpływ myśli libertyńskiej w odniesieniu do jej poprzedników i następstw. 
kryzysu jego oddzielona egzystencja jest najjaśniejsza. Gdzie kryzys jest najgłębszy, tam największy jest pogłos boskiej mocy. ${ }^{41}$

Zatem Descartes libertyn: istnieją w nim oba momenty świadomości libertyńskiej, świadomość kryzysu renesansu i nostalgia za tamtą wolnością. I są one u niego, jak u libertynów, oddzielone -wówczas, w koniunkturze lat 20., która jako jedyna wyjaśnia nagła zmianę jego myśli. Ale napięcie między tymi elementami jest u Descartes'a silniejsze, obecna jest nadzieja, możliwość nowego otwarcia cyklu zaś - pożądana. Przewiduje się tu długi wysiłek dalszej drogi. Problemem będzie zaproponowanie nowego punktu złączenia wobec definitywnego przyjęcia horyzontu dualistycznego.

Przeto:ylli Piotr Laskowski i Piotr Michalik

${ }^{41} \mathrm{Na}$ hipostazę wolności ludzkiej w boskości największy nacisk kładł J.P. Sartre (Sartre 1947, 314-335) [1965, 309-330]; powrócimy jeszcze szerzej do tego eseju. 


\section{Wykaz literatury}

Adam, Antoine. 1949. „Baroque et préciosité”. Revue de sciences bumaines 55-56.

Adam, Antoine. 1964. Les libertins au XVII siècle, Textes choisis etprésentés par Antoine Adam. Paris: Buchet/Chastel.

Adam, Antoine. 1935. Théophile de Viau et la libre pensée francaise en 1620. Lille (Paris): E Droz. Alquié, Ferdinand. 1950. La découverte metaphysique. Paris: Presses Universitaires de France. red. Aston, Trevor. 1965. Crisis in Europe: 1560-1660. Essays from «Past and Present». London: Routledge \& Kegan Paul Ltd.

Baron, Hans. „Secularisation of Wisdom and Political Humanism in the Renaissance”. Journal of the bistory of ideas 21 .

Bonfantini, Mario. 1964. La letteratura francese del XVII secolo. Nuovi problemi e orientamenti. Napoli: Mondadori.

Bontems, Claude i Raybaud Leon Pierre i Braucourt Jean Pierre. Le prince dans la France des XV Ie et XVIIe siècles. Paris:Presses universitaires de France.

Borkenau, Franz. 1934. Der Übergang vom feudalen zum bürgerlichen Weltbild. Studien zur Geschichte der Philosophie der Manufakturperiode. Paris: Alcan.

Braudel, Ferdinand. 1953. Civiltà ed imperi del Mediterraneo nell'età di Filippo II. Torino: Giulio Einaudi.

Braudel, Ferdinand. 1976-1977. Morze Śródziemne i świat śródziemnomorski w epoce Filipa II. T 1-2. Tłum. Tadeusz Mrówczyński i Maryna Ochab (t. 1), Marcin Król i Maria Kwiecińska (t. 2). Gdańsk: Wydawnictwo Morskie.

Bréhier, Emile. 1937. „La création des vérités éternelles dans le système de Descartes”. Revue philosophique de la France et de l'étranger $62: 15-29$.

Busson, Henri. 1933. La pensée religieuse française de Charron à Pascal. Paris: Vrin.

Busson, Henri. 1957. Le rationalisme dans la littérature française de la Renaissance (1533-1601). Paris: Vrin.

Cantimori, Delio. 1959. „La periodizzazione dell'eta del Rinascimento”. W Studi di storia. Torino.

Cantimori. Delio. 1959. „Il problema rinascimentale proposto da Armando Sapori”. W Studi di storia. Torino.

Charles, Adam i Paul Tannery. 1964-1971. Oeuvres de Descartes. Paris: Vrin.

Church, William, Farr. 1941. Constitutional Thought in XVIth century France. A study on evolution of ideas. Cambridge: Mass.

Cohen, Gustave. 19220. Écrivains français en Hollande dans la première moitié du XVIIe siècle, Paris: Librairie Ancienne Edouard Champion.

Dagens, Jean. 1952. Bérulle et les origines de la Restauration catholique (1575-1611). Paris: Desclée deBrouwer.

Descartes, René. 1989. „À Mersenne, 15.04.1630”. Tłum. Stanisław Cichowicz. W Alquié, Ferdinand.Kartezjusz. Warszawa: Instytut Wydawniczy PAX.

Descartes, René. 1989. „À Mersenne, 16.04.1630”. Tłum. Stanisław Cichowicz. W Alquié, Ferdinand. Kartezjus‡. Warszawa: Instytut Wydawniczy PAX.

Descartes, René. 1989. „À Mersenne, 27.05.1630”. Tłum. Stanisław Cichowicz. W Alquié, Ferdinand. Kartezjusz. Warszawa: Instytut Wydawniczy PAX. 
Descartes, René. 1989. „À Mersenne, 25.11. 1630”. Tłum. Ewa Wende. W Alquié, Ferdinand. Kartezjusz: Warszawa: Instytut Wydawniczy Pax.

Descartes, René. 1958. Medytacje opierwszej filozofii. Tłum. Stefan Swieżawski. Warszawa: PWN1958.

Descartes, René. 1989. „Studium Bonae Mentis”.Tłum. Grzegorz Mitrowski. W Ziółkowski, Andrzej. Filozofia René Descartes'a. Warszawa: Wiedza Powszechna.

Febvre, Lucien. 1957. „Libertinisme, Naturalisme, Mécanisme”. W Au coeur religieuxdu XVIe siècle, Paris: S.E.V.P.E.N.

Garin, Eugenio. 1965. Scienza e vita civile nel Rinascimento italiano. Bari: Laterza.

Garin, Eugenio. 1967. „Prefazione”.W Descartes, René, Opere, tom I, Bari: Laterza.

Gilson, Étiennes. 1925. René Descartes. Discours de la méthode. Texte et commentaire. Paris: Vrin.

Gilson, Étiennes. 1930. Etudes sur le rôle de la pensée médiévale dans la formation du système cartésien: deuxième partie des études de philosophie médiévale. Paris: V rin.

Gilson, Étiennes. 1913. La liberté chez Descartes et la théologie.Paris: Alcan.

Gouhier, Henri. 1924. La pensée religieuse de Descartes.Paris : V rin.

Gouhier, Henri. 1951. „Pour une histoire des $<<$ Meditations métaphysiques $>>$ >. WRevue des sciences humaines, tom 61.

Gregory, Tullio. 1961. Scetticismo ed empirismo: studio su Gassendi. Bari: Laterza.

Hagmann, Moritz. 1955. Descartes in der Auffassung durch die Historiker der Philosophie. Zur Geschichte der neuzeittichen Philosophiegeschichte. Winterthur: Keller.

Lecler, Joseph. 1955. Histoire de la tolérance au siècle de la Réformation. Paris: Aubier- Montaigne.

Lecler, Joseph. 1964. Historia tolerancji w wieku reformacji. Tłum. L. Kühn, H. Kühn. Warszawa: Instytut Wydawniczy Pax.

Lenoble, Robert. 1943. Mersenne ou la naissance du mécanisme. Paris: Vrin.

Mandrou, Robert. 1960. Le baroque européen. Mentalité pathétique et révolution sociale". Annales ESC15: 5 : 898-914.

Mandrou, Robert. 1959. „Le soulèvements populaires et la société française du XVII siècle”. Annales ESC $14: 4: 756-765$.

Mousnier, Roland. 1958. „Recherches sur les soulèvements populaires en France avant la Fronde", Revue d'bistoire moderne et contemporaine 5.

Negri, Antonio. 1967. „Problemi di storia dello stato moderno. Francia: 1610-1650”. W Rivista critica di storia della filosofia. Firenze: La nuova Italia: XXII, 2.

Pintard, René. 1937. „Descartes et Gassendi”. W Congrès Descartes. Etudes cartésiennes. Paris. Pintard, René. 1943. Le libertinage érudit dans la première moitié du XVII siècle. Paris: Boivin.

Popkin, Richard Henry. 1964. The History of Scepticism from Erasmus to Descartes. Assen: Van Gorcum.

Porchnev, Boris. 1964. „Les soulèvements populaires en France de 1623 à 1648”. W Revue suisse d'histoire. Paris: S.E.V.P.E.N.

Orcibal, Jean. 1965. Le Cardinal de Bérulle. Evolution d'une spiritualité, Paris: Cerf.

Picot, Gilbert. 1948. Cardin Le Bret(1558-1655) et la doctrine de la Souveraineté. Nancy: Société d'impressions typographiques.

Rice, Eugen Junior. 1958. The Renaissance Idea of Wisdom. Cambridge: Mass : Harvard University Press.

Romano, Ruggiero. 1962. „Tra XVIe XVII secolo: una crisi economica, 1619-1622”. W Rivista storica italiana: 74. 
Sartre, Jean Paul. 1947. „La liberté cartésienne”. Situations V, I. Paris.

Sartre, Jean Paul. 1965. „,Wolność kartezjańska”. Tłum. I. Tarłowska. W Filozofia i socjologia XX wieku. Tom 2. Warszawa: Wiedza Powszechna.

Sirven, Jean. 1930. Les années d'apprentissage de Descartes 1596-1628. Revue néo-scolastique de philosophie 32 No. 27: 373-375.

Spink, John Stephenson. 1960. French free- thought from Gassendi to Voltaire. London: Athlon Press.

Spink, John Stephenson. 1974. Libertynizm francuski od Gassendiego do Voltaire'a. Tłum. A. Neuman. Warszawa: Książka i Wiedza.

Tenenti, Alberto. 1963. „Milieu XVI siècle, début XVII siècle. Libertinisme et hérésie”. Annales ESC $18: 1: 1-19$.

Vivanti, Corrado. 1964. „Le rivolte popolari in Francia prima della Fronda e la crisi dels secolo XVII'”. W Rivista storica italiana 76.

Vivanti, Corrado. 1963. Lotta politica e pace religiosa in Francia fra Cinque e Seicento. Torino: Einaudi.

Von Martin, Alfred. 1951. „Die bürgerlich- kapitalistische Dynamik der Neuzeit seit Renaissance und Reformation". W Historische Zeitschrift 172.

Von Albertini, Rudolf. 1951.Daspolitische Denken in Frankreich zur Zeit Richelieus. Marburg: Simons Verlag.

Von Martin, Alfred. 1932. Soziologie der Renaissance. Stuttgart: Beck.

Wahl, Jean. 1953. Du role de l'idée d'instant dans la philosophie de Descartes.Paris: Alcan. 
Antonio Negri - włoski filozof i działacz polityczny, wykładał m.in. na Uniwersytecie w Padwie, École Normale Supérieure w Paryżu oraz Université de Paris VIII. W latach sześćdziesiątych i siedemdziesiątych brał czynny udział w działaniach na rzecz włoskiego ruchu robotniczego (jako współzałożyciel Potere Operaio i Autonomia Operaia). Autor licznych publikacji poświęconych nowożytnej filozofii politycznej, marksizmowi, globalizacji i transformacjom pracy, m.in. Marx oltre Marx: Quaderno di lavoro sui Grundrisse (1979), Les Nouveaux espaces de liberté (1985, wspólnie z Félixem Guattarim), Il lavoro di Giobbe: Il famoso testo biblico come parabola del lavoro umano (1990), Powrót: Alfabet biopolityczny. Rozmowa z. Anne Dufourmentelle (2002, wydanie polskie 2006), Goodbye Mr Socialism (2006, wydanie polskie 2008, rozmowa z Rafa „Vavolim” Scelsim), Storia di un comunista (2015) oraz pięciu książek napisanych wspólnie z Michaelem Hardtem: Labor of Dionysus: A Critique of the StateForm (1994), Imperium (2000, wydanie polskie 2005), Multitude: War and Democracy in the Age of Empire (2004), Rzecz-pospolita. Poza własność prywatna i dobro publiczne (2009, wydanie polskie 2012), Declaration (2012).

\section{DANE ADRESOWE:}

Université Paris-VIII

Vincennes-Saint Denis

2 rue de la Liberté 93526

Saint-Denis, France

EMAIL: a.negri@free.fr

CYTOWANIE: Negri, Antonio. 2016. Filozofia i koniunktura. Praktyka Teoretyczna 1(19): 104-123.

DOI: $10.14746 /$ prt.2016.1.7

\section{AUTHOR: Antonio Negri}

TITLE: Philosophy and "Conjecture" (from Descartes Politico).

ABSTRACT: In the text, which consists of the first two parts of the second chapter of Descartes Politico, Antonio Negri defines the change in the thought of René Descartes which took place at the end of the third decade of the 17th century. A crucial category in Descartes' thought - conjuncture - is connected closely with the economic downturn and deep crisis of the Renaissance project. Negri tries to capture the moment of birth of the "baroque" Descartes and points to a dynamic tension between Descartes' philosophy (at that particular moment) and a libertine worldview. This ambiguous relation with libertinism (which is the answer to the decline of Renaissance hopes and aspirations) is, according to Negri, the starting point for the Cartesian search for a way to overcome the crisis.

KEYWORDS: Descartes, conjuncture, Renaissance, memory, libertinism, God, bourgeoisie. 